people where there is stability of employment, good communications and working conditions and effective education and training. The training and re-training of operators was discussed by C. V. Kettle, of Lankro Chemicals, Ltd., who emphasized the trend towards less operators and more supervising, the supervision of plant rather than men. Among operators, although new and increased skills are necessary, 'knowledge' is becoming relatively more important than traditional 'skills'. There is a need for knowing 'why' as well as 'how'. Decisionmaking is increasing in importance at oporative level. It is necessary for early recognition of faults and ability to determine the cause. Operators now need to be more adaptable and, at the same time, to move out of the 'arts' class of 'sniffing', 'tasting' and 'feeling' to the use of more sophisticated controls. No longer can he afford to have men 'picking up' tho job by working alongside experienced operators who may be unwilling or incapable of teaching, and who may show the newcomer short cuts without warning of the hazards.

Training of new employees and re-training of presentday operatives can help to overcome such problems. To match the pace of change, operators may need re-training four or five times in their working lifo as opposed to the 'once for all' training. The basic approach should be a methodical analysis of the job to discover: (1) its purposo; (2) the qualitios, quantities and uses of the product; (3) knowlodge of the plant, equipment and raw materials; (4) any special techniques involved; (5) safety factors concerned and attitudes required; (6) faults which may occur at infrequent intervals. From such an analysis an instruction manual can be prepared, the tasks being divided into suitable portions and consideration given to methods of presentation. In presenting training, interest and a sense of worth-whileness must be created at the earliest stage. Instruction should be varied, that is, interwoven practical activities with classroom instruction and discussion. The pace of instruction should be adjusted to the capacity of the learner and must be given in reasonably sized portions which can be practised and shown to be understood before the next portion is tackled. Portions are then combined until eventually the whole job is being performed at the required standard.

There should be a specific person responsible for instructing. Such a person could be selected and developed for this specialist function. In-training of oporators can often be effectively supported by external courses organized by technical colleges, industrial safety training centres, manufacturers of equipment, employors' associations, and the Ministry of Labour. In the next 5-10 years 'automated teaching' will be playing a substantial part in the training of operators.

Three other papers dealt with the optimum utilization of physical resources in chemical plant. G. W. Sears, of Shell Chemical Co., Ltd., discussed the role of linear programming and its significance in planning the production of large-scale continuous processes. The use of linear programming was also described by A. Battersby, of the Work Study School at Cranfield, who, by means of a case study, indicated how a linear programming matrix of the plant could yield information which could be useful in planning not only the manufacturing process but also the plant and its products. Finally, J. Roughley, of Peter Spence and Sons, Ltd., considered the role of maintenance planning in relation to production and indicated that objective maintenance study is a major factor in total manufacturing oconomy.

The value of the symposium was reflected by the large size of the audience and the worth-whileness of the discussions.

T. H. HawkINS

\title{
APPLICATION OF SCIENCE AND TECHNOLOGY FOR THE BENEFIT OF THE LESS-DEVELOPED AREAS
}

$\mathrm{T}$ HE papers prepared by the United States for the United Nations Conferonce on the Application of Science and Technology for the Benefit of the Lessdevelopod Areas in February 1963 have now been published by the United States Agency for International Development in a series of twelve volumes*. These represont an impressive contribution to the growing body of literature in the United States on the problems and processos of development, and on the experience and techniques which could assist those engaged in planning and executing development. The various sections are generally well supplied with reforences, and there are cross-reforences from one volume to another when particular papers are of intorest in more than ono context, while the Agency has issued as a companion volume to the sories a Selected Reading List which briefly describes some 1,200 books and articles dealing with this field recently published in the United States. Somo of the

* Science, Technology and Development: United States Papers prepared for the United Nations Conference on the Application of Science and Technology for the Benofit of the Less Developed Areas. Vol. 1: Natural Re sources-Energy, Water and River Basin Development. Pp. ix +378 . 1.25 dollars. Vol. 2: Natural Resources-Mineral and Mining; Mapping and Geodetic Control. Pp. vii + 355. 1 dollar. Vol. 3: Agriculture. Pp. $\mathrm{x}+262$ 75 cents. Vol. 4: Industrial Development. Pp. ix +90.55 cerits. Vol. 5 Transportation. Pp ix +165.50 cents. Vol. $6:$ Health and Nutrition. Pp $\mathrm{vi}+196.60$ cents. Vol. 7 . Social Problems of Development and Vrbanisation. Pp. Ix +89 . 35 cents. Vol. 8: Organisation, Planning and Programming for Economic Development. Pp. $\mathrm{x}+144.45$ conts. Vol. 9: Screntific and Tech nolagical Policy, Planning and Organisation. Pp. xi+60. 30 cents. Vol. 10 : International Co-operation and Problems of Transfer and Adaptation. Pp.
vili +63 . 30 cents. Vol. $11:$ Human Resources-Training of Scientific and Technicat Personnel. Pp. xii +204. 60 cents. Vol. 12: Communications. Ppo2-63.) articles represent collaboration between American specialists and their professional colloagues in other countries: all the authors wore chosen as recognized experts and soholars in their fields and they includo, for example, such well-known names as those of Dr. J. R. Killian, Dr. A. V. Astin and Prof. H. D. Lasswell.

It is impossible here to do more than indicate the scope of the whole series by noting some of the sections in the various volumes. Vol. 1, dealing with energy, water and river basin development, has sections on: problems of electrification; mining and efficiency in use of coal; achieving productive capacity of oil; nuclear energy; economics of choice among alternative energy sources; water and river basin devolopment, including low-cost waste treatment and desalination. Vol. 2, on minerals and mining, has sections on: the role of government; the co-operative approach; planning and staffing for mineral development; exploration techniques; extracting and processing the ore; and on mapping and goodotic control. Vol. 3, on agriculturo, includes sections on institutional and social aspects of agricultural develop. ment; improvements in levels of nutrition; development of land, and water resources; crop production and protection; animal health and breeding; forestry and fishery resources and production. Vol. 4, on industrial dovelopment, includes sections on: approaches to in dustrial development; essential programmes and key institutes; industrial analyses; and product analyses.

The papers presented in Vol. 5 deal with transportation. covering transport by rosd, rail and water, the movement 
of commodities by pipeline, new techniques of the temperature control of perishable goods in transport and storage applicable to the less-developed areas, and the implications of present scientific research for transport in the future. Papers in Vol. 6, which tackles health and nutrition, are arranged under : planning for health services; the control of diseases; and research and planning (including papers on the provision of facilities for medical research and its future organization and on the role of medical research in less-developed areas. Those in Vol. 7 on social problems of development and urbanization include one on patterns of world-wide cultural change in the 1960's and others on a theory of community development, the implications of urbanization and the role of the family in industrialization. Papers in Vol. 8, on organization, planning and programming for economic development, are grouped under: the methodology of development planning; techniques used; and implementation of development planning.

Vol. 9, covering scientific and technological policy, planning and organization, is of rather more general scientific interest and includes three papers (one by $\mathrm{Dr}$. $J$. R. Killian, jun.) on issues of policy and planning (including one on the loss of scientists from less- to more- developed countries), followed by three on instruments of scientific and technological policies, such as the role of a research institute, of the national laboratory, and on agricultural and industrial extension services to diffuse technological knowledge. The eight papers comprising Vol. 10 deal with international co-operation and problems of transfer and adaptation, and rang ${ }^{\circ}$ from international culture, technical assistance, voluntary association and development to co-operation programmes for strengthening engineering education. Vol. 11, on human resources, is in two parts, the first covering human resources generally, including public mankgoment, management and skilled supervision and occupational safety. The second, dealing with training of scientific and technical personnel, has three papers in a section on planning policies for development of scientific and technological personnel, one of which discusses the programming of science and technology within the educational system, and seven in a section on programmes for educational development. Vol. 12, on communications, is arranged in four sections: unification and expansion through telecommunications; broadcasting and television in less-developed areas; development of national and international telecommunication networks; and telecommunications in specialized fields.

\section{ELECTRON MICROSCOPY}

$\mathrm{T}$ HE electron microscope, since its first crude prototype thirty years ago, has transformed our notions of cytoplasm from that of a homogeneous colloidal system to that of an intricacy of precisely organized structuresmitochondria, plastids, ergastoplasm, Golgi bodies, neurofilaments, synaptic vesicles, and so on--each distinguished by a characteristic sub-microscopical architecture which has proved to be quite remarkably uniform throughout the animal and plant kingdoms. The Medical Department of the British Council recently issued an excellent collection of fourteen short thematic essays intended to provide, according to Dr. V. E. Cosslett in the introduction, "an interim assessment of the contribution the electron microscope is making in medical research" *.

Three excellent papers, respectively by M. A. Epstein, by A. F. Howatson and (jointly) by R. W. Horne and P. Wildy, survey and illustrate the ultra-structure of viruses, the last paper reviewing the use of negativestaining techniques in the elucidation of the molecular structure of viruses and phages. Valuable as these three papers on viruses are as special instances, they give an inadequate impression of the contribution being made by the electron microscope to what might be called the biology of virus infection - the sites of virus multiplication within cells, the time and manner of their release, and so on. Then the short review by Audrey Glauert on the fine structure of bacteria, and that by A. V. Grimstone on the ultra-structure of cilia and flagella, show how a new dimension, both scientific and æsthetic, is now being added to descriptive bacteriology, and the paper by R. C. Valentine shows how the electron microscope has been applied to estimate the viability of that most baffling of all pathogenic micro-organisms, the leprosy bacillus.

The study of tissue structure is exemplified in reviews by J. A. Chapman on collagen and fibrogenesis, on melanoeytes by M. S. C. Birbeck, on the fine structure of endocrine cells by J. D. Lever, on the cytology of the organ of Corti in the inner ear by I. Friedmann, on testis structure and function by D. Lacy and on the cancer cell by E. H. Mercer. The nervous system is represented by an excellont paper by V. P. Whittaker and E. G. Gray on the synapse: their successful isolation of nerve endings in

* Electron Microscopy. British Medical Bulletin, 18, No. 3. September good state of preservation, using the methods of subcellular fractionation, opens up exciting possibilities for the identification of hitherto unknown transmitter substances. The gains in the aforementioned fields of 'straight' morphology have been tremendous, and although much awaits us-particularly in the study of the pathological cell and cellular products-by such straightforward ultra-structural study, there are already intimations of new fields opening up by the use of specific electron stains for enzyme localization at the subcellular level, as exemplified in the paper here by S. J. Holt and R. M. Hicks.

This is a compilation of special themes by experts, mostly electron microscopists or cytologists, on their own subjects and is in no sense a text-book or monograph on electron microscopy in medical research. Therefore, in assessing the contribution of the electron mieroscope to medicine, we must supplement these papers in our own minds with the now almost innumerable details of normal and abnormal structure and function which the high resolution of the microscope has clarified-tho nature of the 'blood-brain-barrier', the process of myelin sheath formation, the structure of the motor end-plate, the muscle fibre fine structure, the fine structure of the plasma cell and other cells involved in immunological processes, etc.; and, not least, its important role as monitor of coll fractionating methods used by the cell chemist.

Finally, as Dr. V. E. Cosslett says in the introduction, the chief remaining technical or physical problem of electron microscopy is that of examining living matter. The difficulty is that, to protect the living cell from exposure to vacuum, it must be exposed in a chamber with walls thick enough to prevent evaporation but thin enough to be penetrated by the electron beam. Even with a small bacterium the total thickness of the preparation can scarcely be less than 1 micron; a beam voltage of at least $500 \mathrm{kV}$ is neoded to penetrate this distance and still yield a reasonably clear electron picture. Such a high-voltage electron microscope has now been built at the University of Toulouse and the first micrographs of living bacteria have been published (Dupouy et al., C.R. Acad. Sci. (Paris), 251, 2836; 1960). We may bo within sight of electron-beam time-lapse studies of cells in tissue culture.
C. E. LUMSDEN 